\title{
Kalesang Village Program
}

\author{
Tim Kerja PSP2M Uniqbu
}

\begin{abstract}
The village Kalesang Program is a government business of Buru Regency to improve the lives of the village community with participatory planning patterns that come from the government and society. The Kalesang village includes the planning and implementation of Village development conducted jointly between the Government and the village community. This research is a qualitative study aimed at describing the implementation of the village's Kalesang program as a poverty alleviation instrument in rural communities. The research location focuses on Lala, Namlea and Marloso with the consideration of different social economic characters with other villages in Namlea subdistrict. The number of informant interviewed was 45 people divided into communities, village apparatus and community leaders. Analytical techniques used to follow the concept of Miles and Huberman where activities in the analysis of qualitative data are conducted interactively and continuously. The results showed that the village's Kalesang program was able to become a development instrument and empowerment that was able to foster cooperation from the Community and government to plan and implement development and to keep watching it Through active participation. The end goal of the village Kalesang in the form of poverty testing made easy in the frame of harmonization and synergy between the government and the community to cooperate in resolving the problem of Village development.
\end{abstract}

Keywords: Kalesang Desa, Poverty, Community, Village, Empowerment

\section{INTRODUCTION}

Namlea subdistrict is the capital of Buru Regency consisting of 11 villages and 9 hamlets. The area of Namlea subdistrict is $226.55 \mathrm{~km}^{2}$ and has the largest population in Buru Regency. Inhabitants of Namlea sub-district according to the data of Central Statistic Bureau year 2018 is 34,326 inhabitants. This number has increased steadily every year with a population growth rate of 6.26 percent (BPS Data, 2018)[1]. With the addition of this population, it automatically results in a higher level of population density that indicates more and more problems that will arise as poverty develops in societal life.

One of the efforts of the local government of Buru regency in alleviating poverty is implementing the village's Kalesang program as an effort to approach the handling of poverty that occurs in rural communities. "Kalesang Desa" is essentially a courage to think beyond the shell, the spirit out of the shackles of safe zones and the spirit to break down old habits into an attitude that is adaptive, positive, optimistic, apreciprocative and Democratic[2].

The village's Kalesang program in Buru District is a breakthrough program focused on education, health and the potential of village mainstay, including forms of local wisdom in each village that needs to be preserved[3]. Kartasasmita mentions the poverty alleviation policy can be contained in the three-way policy. Firstly, indirect policies are directed at the creation of conditions that ensure the continuity of every poverty alleviation effort; Second, direct policy addressed to low-income communities; and third, special policies that are intended to prepare the poor community itself and officers who are directly responsible for the smoothness of the program and simultaneously spur and expand poverty alleviation efforts[4].

The correlation between the village's Kalesang program with the three-way policy presented by Kartasasmita is the third part as intended that the village's Kalesang program is a special policy intended for problem solving Poor people in Buru regency with the involvement of regional device organizations as an apparatus responsible directly for the smooth program and also spur and expand the efforts of poverty reduction.

The background in his research on the implementation of village Kalesang in Buru Regency[5], found the village's Kalesang program that carried out in every field is not fully successful. Programs that cover the field of education, health, village government organizing, village Community empowerment, improvement of village infrastructure and increased spiritual mental has a dependence on the involvement of local governments due to centralist implementation patterns from local governments to village communities.

Mazuindianto in his research on poverty alleviation in the village of Edema Seri Kuala Lobam series through a joint business group program found at the level of the Unit and Department and section has not succeeded as a result of not synergided executive apparatus program, so that in conclusion[6], KUBE program has not been able to eradicate poverty in the village of Busung[7]. This research was conducted based on the preference of the implementation of village Kalesang program in Namlea District as a poverty reduction effort in Buru Regency. In addition, the research aims to obtain a primary picture of the relationship that awakens between the government of Buru and the village community as well as the logical consequences that affect resource utilization in Namlea subdistrict.

\section{LITERATURE REVIEW}

\subsection{Village Goverment}

The implementation of village governance is a subsystem of the national governance system, so the village has the authority to regulate and manage the interests of the community. According to Act No. 6 of 2014, article 23 is confirmed by the village government. Article 25 "The village government as referred to in article 23 is the head of village or called by another name and which is assisted by the village device or called by another name." Further article 48 "The village device consists of the secretariat of villages, regional executor and technical executor". The village chief is tasked with organizing the village 
government, implementing Village development, village community coaching and Village Society empowerment[8]. Village government is one elements of government organizers in the village have a big responsibility, both poor governance will be highly dependent on the performance of the village apparatus as an element of organizers. The implementation of village governance will be organized and better directed, even more advanced when the performance of village officials in providing services in accordance with the principles of the village governance are accountable, transparent, professional, effective and efficient, clean and free of collusion, corruption, and nepotism[9]. One of the functions of government administration is public service conducted by government officials. Village officials are officers appointed by the competent authorities to carry out government duties relating to the service of the community[10]. The village government under the head of the village has the task of: (1) Organizing government, development and Community affairs efficiently and accountable, (2) conducting government affairs bestowed by the Regent. Thus, the village government conducts functions of government administration, community empowerment, community services, peace and public order implementation, maintenance of infrastructure and public facilities, and development of institutions Community[11]. However, in the lowest level of government is the village, there are many events that are related to low government service to the community both in quality and quantity.

\subsection{Kalesang Desa}

Kalesang Village consists of two syllables namely Kalesang and Desa, etymologically Kalesang derived from the language of Ambon which is classified as a clumps or dialok of the standard Malay language in the provisions of Maluku province which contains the meaning of caring, preserve, administer, repair, nurture, organize, build or improve, where in principle the meanings have the same purpose that is the effort to build towards a better state[12]. While the village according to law number 32 year 2004 about the local government is "the unity of the law community that has the boundaries of jurisdiction, authorized to organize and manage the interests of local people based on the origin of Local customs recognized and in the form of the national government system and located in the district, as referred to the Constitution of the Republic of Indonesia year 1945.

Kalesang Desa in essence is the courage of thinking and spirit to try and the spirit to change the old habits, the establishment of a culture of the village Kalesang is the attitude. The attitude is adaptive, positive, optimistic, apreciprocative and democratic[13]. The main foundation of Kalesang Desa program is the process of governance in the field of development of the village has not been carried out in an integrated way, tends to be wasteful, sporadic and masiv. This indicates that the existence of synchronized between the level of central and local governments both from the funding side and the target of the implementation of the activity is finally felt by the people not maximally.

Kalesang Desa Program is prepared with the aim of (1) encouraging community participation in the field of government, development and public services, infrastructure in the village in accordance with local characteristics and wisdom (2) Accelerate Governance and improvement of human resources of village governance Apparatus (3) creating an independent and productive society from the Economic aspects (4) improving the mental and spiritual society according to the value of religious values and beliefs Embraced[14].

Funding of the Kalesang Village program is divided into two (two) parts, the first is the funding of the Coordination Team Kalesang Desa and both funding in the implementation of the village Kalesang. Funding of the Kalesang Desa program is done with an integrated and systemic system involving all the local devices in Buru Regency with state funding. The stage of implementation is a stage that determines the success or absence of the program Kalesang Desa because at this stage, the component that is responsible for the implementation of the village's Kalesang program in the demands to work earnestly according to With its tasks and functions.

\subsection{Poverty}

Poverty is now a multidimensional development problem. Poverty can be easily identified and characterized by the conditions of retardation, hellessness, and incapacity of the economy, as well as the number of unemployment of the population, which subsequently becomes a trigger of income inequality and Gap between the population[15]. Poverty can be defined as a living condition with a very low standard of life. Poverty can also be defined as a condition where one cannot fulfill the basic life as a human, especially food and clothing. Some of the common concepts of poverty are absolute poverty and relative poverty. Absolute poverty can be classified into two parts namely (a) poverty to meet basic needs and (b) poverty to meet higher demands[16].

The National Development Planning Agency (Bappenas) uses several key approaches in establishing poverty lines, among others, basic needs approaches and income approaches. The basic need approach is to see poverty as an inability of a person, family, and society to meet minimum needs, such as food, clothing, boards, health services, education, water supply, and sanitation. The approach of income sees poverty caused by low mastery of assets and productive tools such as land, farmland and plantation, thereby directly affecting the income of people in the community[17]. Variables to determine whether a household is worthy or not said to be poor, it also determines the severity of its poverty, the size of the house building, the type of floor, type of wall, the facility of defecation, the source Drinking water, lighting source, fuel type used for cooking, the frequency of buying meat, chicken, and milk a week, the frequency of meals a day, the set number of new clothes purchased a year, access to hospitals or polyclinics, job fields, The highest education of the head of the household, and ownership of some assets both moving and unmoving assets. 


\section{Method}

The research was conducted in Namlea subdistrict, Buru regency. The determination of the research site was conducted in Purposive[18] in consideration that Namlea district was chosen as the location of research because it has the largest population and become a sub-village pilot district. The number of informant interviews of 45 people taken in purposive[19] with consideration of respondents is regarded as the parties concerned to achieve research objectives[20]. The informant is a village apparatus, a housewife, a community leader who resides at a research site.

The data on this study was obtained from primary data sources and secondary data, with the data collection techniques used through observation, interviews, questionnaire and library studies[21]. In the interview step researchers conducted a thorough interview with the informant[22] [23] as well as the direct observation of all activities conducted by the informant. Researchers are also looking for complementary information related to local government apparatus activities and discussions with the community. The interview was conducted at 17.00-22.00 where the researchers adjusted the working time and the rest of each informant.

The analytical techniques used in this study are qualitative data analysis following the proposed concept of Miles and Huberman and Spradley[24]. Miles and Huberman, suggests that activities in the analysis of qualitative data are conducted interactively and ongoing continuously at every stage of the research so as to complete and data until saturated. Activity in data analysis is data reduction, data presentation, draw conclusions or verification.

\section{RESULT}

\subsection{General Condition of Community in Namlea Subdistrict}

Namlea subdistrict is administratively the capital of Buru Regency which has several elements of excess, 9 sub-districts in the administrative area of Buru Regency Government. The availability of infrastructure such as offices, education, economic and health facilities makes Namlea a much faster development. The population of Namlea subdistrict, especially in Namlea, changed the demographic aspect.

Table 1.

Number of Viilage and Residents

\begin{tabular}{ccc}
\hline \hline Village & \multicolumn{2}{c}{ Population } \\
\cline { 2 - 3 } & Male & Women \\
\hline Namlea & 10.324 & 12.975 \\
Lala & 1043 & 1165 \\
Karang Jaya & 2312 & 2400 \\
Jamilu & 1311 & 1366 \\
Siahoni & 523 & 454 \\
Sanleko & 1184 & 1231 \\
Batu Boy & 647 & 731 \\
\hline \hline
\end{tabular}

Source: Subdistric Namlea Monograph, 2019.

The table above shows the number of inhabitants in Namlea subdistrict. The number of women seems to be more than men. Potential demographic is the reason for the local government of Buru regency for development oriented on the development of micro enterprises and human resource empowerment.

Table 2.

Social Culture Character of Society

\begin{tabular}{cl}
\hline \hline Village & \multicolumn{1}{c}{ Character } \\
\cline { 2 - 4 } Lala & \multicolumn{1}{c}{ Social stratification in the Open and receive an } \\
& $\begin{array}{l}\text { community based on the outside person visiting } \\
\text { size of education and the Tillage. The }\end{array}$ \\
& economic resources. contribution of people in \\
& Social cohesion is more of the form of material, \\
a stretch. Social energy, and mind for \\
institutional community village activities. Society \\
to become citizen has a strong bond in \\
communication room living religious teachings \\
Social stratification in Quite open in reception of \\
society based on job size, outside people visiting \\
education and economic the village. The action of \\
mastery. Social cohesion the development is \\
is more of a stretch. deferentiation based on \\
Social institutional the environment of
\end{tabular}




communities are residence and local area.
increasingly difficult to People have cultural ties
develop and become based on ethnic and
formal regional origin
Marloso
$\begin{aligned} & \text { Social stratification in } \\ & \text { the community based outside people visiting }\end{aligned}$
on the size of education the village. The Act of
and economic resources. building contributions
Social cohesion is more based on family ties.
of a stretch. Social Society has a strong bond
Institutional society in living religious
becomes a formal teachings
communication room

The social character community in Namlea sub-district which is scattered in seven villages is very open to the reception of people who visit the village and the action of development contributions is always based on the kinship system. In addition to the social Stratification in society based on the size of economic and cultural resources.

Table 3.

Village Development Orientation

\begin{tabular}{|c|c|c|c|}
\hline \multirow[t]{2}{*}{ Village } & \multicolumn{3}{|c|}{ Orientation of Development } \\
\hline & Infrastructure & Economic & Social \\
\hline Lala & $\begin{array}{l}\text { Improvement of } \\
\text { village entrance } \\
\text { access, and beach } \\
\text { location } \\
\text { arrangement }\end{array}$ & $\begin{array}{l}\text { Development of } \\
\text { poor } \\
\text { community } \\
\text { capacity }\end{array}$ & $\begin{array}{l}\text { Improving the } \\
\text { quality of } \\
\text { religious faith } \\
\text { and steadquism }\end{array}$ \\
\hline Namlea & $\begin{array}{l}\text { Development of } \\
\text { community } \\
\text { learning facilities, } \\
\text { road maintenance } \\
\text { and handling of } \\
\text { waste problems }\end{array}$ & $\begin{array}{l}\text { Development of } \\
\text { village } \\
\text { Economics and } \\
\text { development of } \\
\text { community } \\
\text { independent } \\
\text { Business } \\
\text { Network }\end{array}$ & $\begin{array}{l}\text { Improved ability } \\
\text { and } \\
\text { professionalism } \\
\text { of village } \\
\text { community } \\
\text { members and } \\
\text { managers }\end{array}$ \\
\hline Marloso & $\begin{array}{l}\text { Improving the } \\
\text { quality of public } \\
\text { services to the } \\
\text { public, } \\
\text { maintenance of } \\
\text { road facilities and } \\
\text { maintenance of } \\
\text { educational } \\
\text { facilities }\end{array}$ & $\begin{array}{l}\text { Development of } \\
\text { poor } \\
\text { community } \\
\text { capacity and } \\
\text { improvement of } \\
\text { village } \\
\text { economic } \\
\text { potential } \\
\text { facilities }\end{array}$ & $\begin{array}{l}\text { Preservation of } \\
\text { village culture } \\
\text { and customs. } \\
\text { Increased order } \\
\text { and security of } \\
\text { villages }\end{array}$ \\
\hline
\end{tabular}

Source: Compilation of Field Research Results March 2019.

As it is known that the development of the village is an effort made by the village government to improve the welfare of the community. It is also implemented by Namlea subdistrict government. In the table above, the orientation is done by the Subdistrict government in the three villages that exist in Namlea village is carried out access to road repair and the arrangement of the location of the beach area for the property and then in the economic sector to implement Poor community capacity development. Then for the social sector the village Government jointly implement the program that the movement of Maghrib Koran. Likewise, in the two villages studied namely, Lala and Marloso village. 


\subsection{Program Implementation}

The implementation of the program was conducted simultaneously in 7 villages in Namlea subdistrict where researchers tried to photograph three important things such as infrastructure, economics and social. Further elaborated how the village Kalesang program implementation in each research site.

Table 4.

Implementation of the Village Kalesang Program

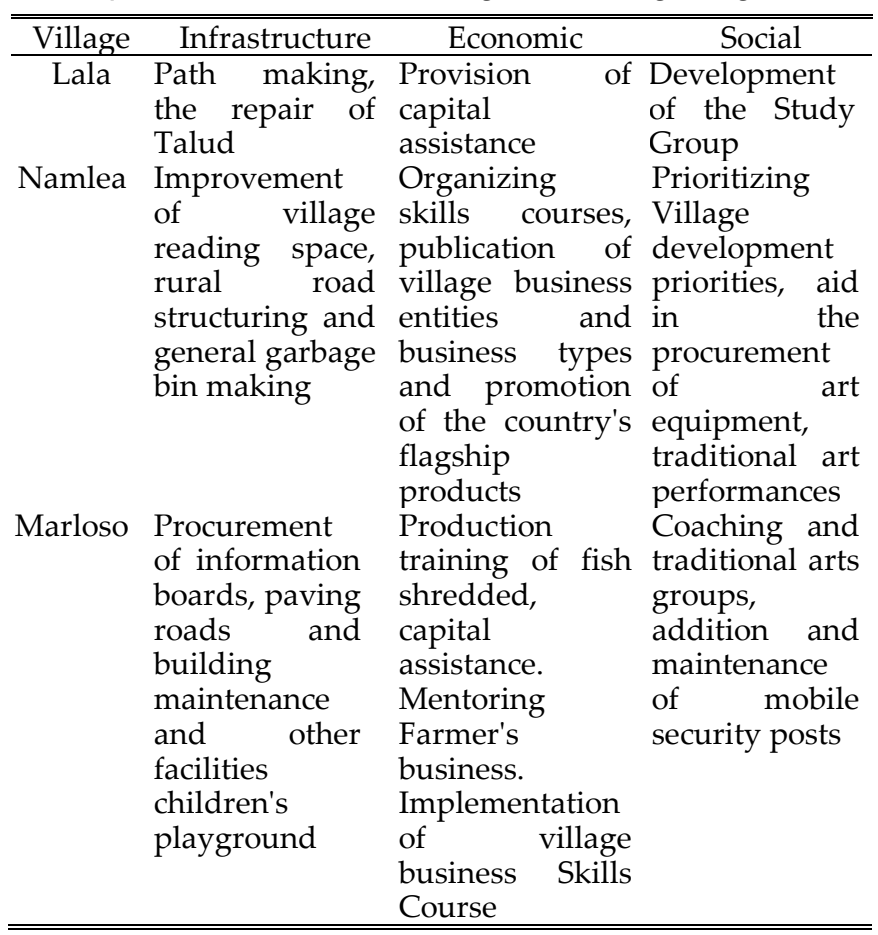

Source: Compilation of Field Research Results March 2019.

Kalaseng Desa Program essentially grows and boosts the economy of the community, which is carried out by three villages, namely Namlea village, Marloso, and Lala. The Program is divided into three implementations, namely infrastructure, economics and social. The three villages differ as they are seen from their respective cultures and customs for example at Namlea Village for the infrastructure for the improvement of village reading space, the arrangement of Hamlet roads and the manufacture of public trash cans, organizing courses Skill, publication of village business entity and type of business and promotion of the village's flagship products, prioritizing Village development priorities, assistance in the procurement of art equipment, traditional art performances.

\section{Discussion}

The implementation of the village Kalesang is a synergity between the desire to change and leave old habits. The study of social economic change of the village indicates that there are roles from various parties such as society, village apparatus, local government where the collaboration of these three elements resulted in harmony in planning, implementation and supervision[25].

Kalesang desa becomes a development and empowerment approach where the development instrument can be found with participatory development pattern from the awakened government and society, while empowerment can be We find in mentoring the implementation of the village Kalesang program.

The character of a village community that is largely homogeneous and has openness to the outside to be a driving factor for the occurrence of acculturation and assimilation of the character[26], the condition can be found in all three research locations So that there is an initiation for a change that comes not only from the element of the Government but also from the village community[27][28].

The implementation of the program reflects that there is a harmony that comes from related elements such as community support to the implementation and the level of community participation in the planning and implementation of the program.

The impact that can be obtained from the overall implementation of the village Kalesang program is able to be an indicator of social economic change of society and open opportunities to the community so that they come out of poverty. There are a few things that we need to look at about the implementation of the village Kalesang namely (1) The change is a public awareness about their condition that increasingly difficult to live daily life so that this awareness becomes a foothold For them to participate in changes planned both by the local government and from the public[29]. (2) The implementation of community development and development is not focused on any of the elements but covering infrastructure, social and economic so that the need for a decent life can be fulfilled[30]. (3) 
Community development towards economic and social resilience is easier to materialize with synergy between human resources, utilization of potential and support of economic network[31]. (4) Kalesang village becomes a vehicle for empowering the village community that can change conditions and encourage people to exit the poverty zone[32].

\section{CONCLUSION}

Kalesang Village is an effort to realize a prosperous society with a pattern of comprehensive empowerment from the government to the public and society to the Government. Key of the village Kalesang lies in cooperation and community participation in planning and running the development program. Kalesang Village has a positive impact where community involvement and local government and regional governments become a power together in creating welfare for the village community so that the sustainability of the village Kalesang program becomes A foothold for improving quality of life and transforming the inability to become a common force in tackling the poverty problem of village society.

\section{REFERENCES}

[1] M. C. B. Umanailo, Sosiologi Hukum, 1st ed. Namlea: FAM PUBLISHING, 2016.

[2] M. C. B. Umanailo, "Integration of Community Empowerment Models [Pengintegrasian Model Pemberdayaan Masyarakat]," Proceeding Community Dev., vol. 2, p. 268, Mar. 2019.

[3] M. C. B. Umanailo, "Discourse on the Consumerist Community Consumption," J. Soc. Sci. Res., vol. 5, no. 54, pp. 1181-1186, Apr. 2019.

[4] M. C. B. Umanailo, "Studi pada Masyarakat Desa Waimangit Kabupaten Buru," SOCA, vol. 12, no. 12, pp. 63-74, 2018.

[5] B. S. Amanto, M. C. B. Umanailo, R. S. Wulandari, T. Taufik, and S. Susiati, "Local Consumption Diversification," Int. J. Sci. Technol. Res., vol. 8, no. 8, pp. 1865-1869, 2019.

[6] M. C. B. Umanailo, "Eksistensi Waranggana Dalam Ritual Tayub."

[7] M. C. B. Umanailo, M. Nawawi, and S. Pulhehe, "Konsumsi Menuju Konstruksi Masyarakat Konsumtif," Simulacra, vol. 1, no. 2, pp. 203-211, 2018.

[8] M. C. B. Umanailo, "Strategi Bertahan Hidup Petani Padi Gogo di Pulau Buru," J. Ekon. Pertan. dan Agribisnis, vol. 3, no. 1, pp. 50-58, Jan. 2019.

[9] M. C. B. Umanailo, "Consumption Diversification of Local Community," J. AGRISEP Kaji. Masal. Sos. Ekon. Pertan. dan Agribisnis, vol. 18, no. 1, pp. 61-74, Mar. 2019.

[10] S. Yusuf, M. C. B. Umanailo, R. N. Putri, D. Qhuril, M. Ely, and D. Darma, "Village Institution Relations in the Utilization of Village Funds in Namlea District," Int. J. Sci. Technol. Res., vol. 8, no. 8, pp. 1837-1842, 2019.

[11] M. C. B. Umanailo, "Postmodernisme dalam pandangan jean francois lyotard," 2018.

[12] M. C. B. Umanailo, "BUPOLO " Movement. 2019.

[13] S. Rachman, H. Hamiru, M. C. B. Umanailo, Y. Yulismayanti, and H. Harziko, "Semiotic Analysis of Indigenous Fashion in The Island of Buru," Int. J. Sci. Technol. Res., vol. 8, no. 8, pp. 1515-1519, 2019.

[14] M. C. B. Umanailo et al., "Cybercrime Case as Impact Development of Communication Technology That Troubling Society," Int. J. Sci. Technol. Res., vol. 8, no. 9, pp. 1224-1228, 2019.

[15] H. Hamiru et al., "Eucalyptus Oil Workers," Int. J. Sci. Technol. Res., vol. 8, no. 9, pp. 1817-1820, 2019.

[16] W. Malmia et al., "Problem-Based Learning as an Effort to Improve Student Learning Outcomes," Int. J. Sci. Technol. Res., vol. 8, no. 9, pp. 1140-1143, 2019.

[17] M. C. B. Umanailo, M. Yulisvestra, K. K. Oki, W. Mulyasari, and R. Ridwan, "The Thought of Emile Durkheim in the Contestation of Development in Indonesia," Int. J. Sci. Technol. Res., vol. 8, no. 8, pp. 1881-1885, 2019.

[18] R. Bugis et al., "Workers in the Namlea Market," Int. J. Sci. Technol. Res., vol. 8, no. 9, pp. 2044-2047, 2019.

[19] M. C. B. Umanailo, Masyarakat Buru Dalam Perspektif Kontemporer (Kajian Kritis Perubahan Sosial di Kabupaten Buru), vol. 1. Namlea, 2017.

[20] M. C. B. Umanailo et al., "Dominance of Economic Capital in Political," in Community Development, Decentralization \& Local Autonomy Politic \& Democracy, Fisip Universitas Brawijaya, 2018, pp. 1-120.

[21] M. C. B. Umanailo, "'recycling' consumerism to construction of modern society," no. 1904, 1964.

[22] L. Molognoni, H. Daguer, I. R. dos Santos, and J. De Dea Lindner, "Influence of method validation parameters in the measurement uncertainty estimation by experimental approaches in food preservatives analysis," Food Chem., vol. 282, pp. 147-152, Jun. 2019.

[23] M. C. B. Umanailo, "Overview of Phenomenological Research," 2019, pp. 1-6.

[24] M. C. B. Umanailo, Marginalisasi Buruh Tani Akibat Alih Fungsi Lahan. 2016.

[25] M. C. B. Umanailo and T. Yatno, Kajian dan Analisis Sosiologi Dalam Bentuk Kumpulan Essay, Makalah dan Opini. 2015.

[26] M. C. B. Umanailo, I. Hamid, M. Nawawi, S. Pulhehe, S. Yusuf, and A. T. Bon, "Utilization of Qualitative Methods in Research Universities," in Proceedings of the International Conference on Industrial Engineering and Operations 
Management, 2019, pp. 2076-2081.

[27] M. C. B. Umanailo, R. Umanailo, R. Bugis, and A. T. Bon, "Empowerment Community in Buru Regency," in Proceedings of the International Conference on Industrial Engineering and Operations Management, 2019, pp. 2070-2075.

[28] M. C. B. Umanailo, N. Handayani, A. Masniati, S. H. Makatita, and S. Lisaholit, "The Urbanization and Diversification of Farmland Namlea Village," Int. J. Sci. Technol. Res., vol. 8, no. 8, pp. 1049-1053, 2019.

[29] L. Rumkel, B. Sam, and M. C. B. Umanailo, "Village Head Partnership, Village Consultative Body and Customary Institution in Village Development," Int. J. Sci. Technol. Res., vol. 8, no. 8, pp. 1058-1063, 2019.

[30] S. S. F. Assagaf et al., "Construction of the Village as a Development Shaft in the Island Buru," Int. J. Sci. Technol. Res., vol. 8, no. 9, pp. 2139-2143, 2019.

[31] A. Hasan Afandi and M. C. B. Umanailo, "Watudakon Citizens 'Social Conflict on Joker Toll Road Development in 2017 in Kesamben District, Jombang Regency," J. Soc. Sci. Res., vol. Special Is, no. 5, pp. 656-661, 2018.

[32] M. C. B. Umanailo, "Keterbatasan penggunaan teknologi informasi pada pelayanan dan pembelajaran di universitas iqra buru," 2016. 